\title{
HUBUNGAN RIWAYAT PAPARAN PESTISIDA DENGAN KEJADIAN GOITER PADA ANAK SEKOLAH DASAR DI WILAYAH KERJA PUSKESMAS KLUWUT KECAMATAN BULAKAMBA KABUPATEN BREBES
}

\author{
Bibit Nasrokhatun Diniah \\ Sekolah Tinggi Ilmu Kesehatan Kuningan Garawangi
}

bibitnasrokhatundiniah@yahoo.com

\begin{abstract}
Abstrak
Tingginya penggunaan pestisida dapat menyebabkan pencemaran lingkungan, keracunan dan terakumulasi pada produk pertanian, sehingga berdampak buruk terhadap kesehatan. Pestisida menyerang sistem saraf, hati, perut, sistem kekebalan dan keseimbangan hormonal. Kabupaten Brebes sebagai produsen bawang merah terbesar di Indonesia terdapat \pm 700 merk pestisida dan merupakan daerah endemis GAKI. Prevalensi goiter tertinggi di Wilayah Kerja Puskesmas Kluwut, sebesar 107 anak positif goiter $(68,6 \%)$. Tujuan penelitian untuk mengetahui hubungan antara riwayat paparan pestisida dengan kejadian goiter pada anak sekolah dasar di Wilayah Kerja Puskesmas Kluwut Kecamatan Bulakamba Kabupaten Brebes.

Jenis penelitian adalah observasional analitik dengan rancangan studi kasus kontrol. Teknik sampling menggunakan metode random sampling dengan 45 kasus dan 45 kontrol. Penentuan kelompok kasus kontrol menggunakan metode palpasi.

Hasil penelitian menunjukkan terdapat hubungan antara keterlibatan anak dalam kegiatan membersihkan bawang $(\mathrm{p}=0,01 ; \mathrm{OR}=3,89)$, mengikat bawang $(\mathrm{p}=0,037 ; \mathrm{OR}=4,74)$, dan personal hygiene anak setelah bermain $(\mathrm{p}=0,04 ; \mathrm{OR}=3,06)$ yang secara signifikan menjadi risiko terhadap kejadian goiter. Upaya preventif dalam meminimalisasi dampak paparan pestisida pada anak-anak adalah dengan melakukan personal hygiene dengan benar, menurunkan lama waktu keterlibatan dalam kegiatan pertanian, dan penggunaan APD.
\end{abstract}

Kata Kunci : Paparan Pestisida, Anak-anak, Goiter

\section{Pendahuluan}

Dampak buruk pestisida bukan hanya mengenai petani atau pekerja yang menyemprot pestisida saja, tetapi juga dapat mengenai keluarga dan tetangga dimana kegiatan itu dilakukan. Keracunan pestisida yang bersifat sistemik dapat menyerang sistem saraf, hati atau liver, perut, sistem kekebalan dan keseimbangan hormonal (M Güven, F Bayram, K Ünlühizarci, 1999)

Selain karena adanya kekurangan iodium kejadian goiter/gondok dapat disebabkan oleh faktor EDC (Endocrine Disruptor Chemical) William F. Ganong (1999). EDC merupakan gangguan kinerja sistem endokrin dan perubahan struktur hormon yang disebabkan oleh zat - zat kimia, salah satunya adalah pestisida. Beberapa tahun terakhir telah dilakukan banyak penelitian tentang hubungan EDC dengan proses terganggunya sistem endokrin, diantaranya dapat menyebabkan gangguan sistem hormonal yang berhubungan dengan perubahan fungsi endokrin akibat adanya bahan kimia 
JURNAL ILMU KESEHATAN BHAKTI HUSADA:

HeALTH SCIENCES JournaL, Vol. 10 No. 02, DeSEMBER 2019

DOI: 10.34305/jikbh.v10i2.90

lingkungan di dalam tubuh (Ejaz S, Akram W, Lim CW, Lee JJ, 2004).

Kabupaten Brebes sebagai sentra produksi bawang merah terbesar di Indonesia dan terdapat \pm 700 merk pestisida yang beredar dan jenis pestisida paling banyak digunakan adalah pestisida dari golongan Organophosphat. Kegiatan pertanian bawang merah tidak hanya dilakukan oleh orang dewasa, namun juga melibatkan anak-anak. Salah satu populasi yang berisiko untuk terpajan pestisida adalah anak-anak yang tinggal di daerah pertanian. Efek negatif dari pajanan pestisida pada kelompok anak-anak dapat menimbulkan berbagai gangguan kesehatan. Hal ini berkaitan dengan keterlibatan anak-anak dalam kegiatan pertanian diantaranya melepaskan bawang dari tangkainya, menjemur bawang, membersihkan bawang, mengikat bawang, dan mencari sisa - sisa hasil panen bawang merah di sawah. Kegiatan tersebut menjadikan anak-anak mengalami kontak langsung dengan residu pestisida yang terdapat pada tanah, dan tanaman bawang merah (Rasipin, 2013).

Dalam penelitian Lambert et al., (2005) pada anak-anak di area pertanian menyebutkan bahwa anak-anak yang dekat

\section{Hasil}

Rekapitulasi Hasil Analisis Bivariat antara faktor-faktor yang berhubungan
Ciptaan disebarluaskan di bawah

Lisensi Creative Commons Atribusi-

NonKomersial-BerbagiSerupa 4.0

Internasional.

dan tinggal di sektor pertanian memiliki risiko 1,92 kali lebih tinggi atau lebih besar untuk keracunan pestisida organofosfat. Dikatakan juga bahwa anak yang tinggal di daerah pertanian risiko terpapar sangat tinggi karena adanya organofosfat yang terbawa ke rumah.

\section{Metode}

Jenis penelitian observasional analitik menggunakan pendekatan metode survei dengan rancangan kasus kontrol. Tujuan penelitian adalah melihat hubungan antara kejadian goiter dengan paparan pestisida yang terjadi pada anak-anak dengan menentukan kelompok kasus dan kontrol yang kemudian diukur paparan yang telah lalu (retrospektif).

Penentuan kelompok kasus kontrol dengan metode palpasi oleh tenaga kesehatan. Kelompok kasus meliputi anakanak yang menderita goiter yang ditandai dengan gejala klinis yaitu pembesaran kelenjar tiroid, sedangkan kelompok kontrol meliputi anak-anak yang tidak mengidap goiter. Kedua kelompok ini kemudian dibandingkan tentang adanya faktor risiko masa lalu terhadap riwayat paparan pestisida.

sebagai Faktor Risiko Kejadian Goiter pada Anak di Wilayah Kerja Puskesmas Kluwut Kecamatan Bulakamba Kabupaten Brebes.

\begin{tabular}{|c|c|c|c|c|c|c|}
\hline No & Faktor risiko & Kasus (\%) & Kontrol (\%) & p value & OR & $95 \% \mathrm{CI}$ \\
\hline 1 & $\begin{array}{l}\text { Kebiasaan bermain } \\
\text { 1) Ya } \\
\text { 2) Tidak }\end{array}$ & $\begin{array}{c}38(84,4 \%) \\
7(15,6 \%)\end{array}$ & $\begin{array}{l}33(73,3 \%) \\
12(26,7 \%)\end{array}$ & 0,302 & 1,97 & $0,69<\mathrm{OR}<5,6$ \\
\hline & Jumlah & $45(100 \%)$ & $45(100 \%)$ & & & \\
\hline 2 & $\begin{array}{l}\text { Keterlibatan 'mbroc } \\
\text { 1) Ya } \\
\text { 2) Tidak }\end{array}$ & $\begin{array}{l}31(79,5 \%) \\
8(20,5 \%)\end{array}$ & $\begin{array}{c}31(88,6 \%) \\
4(11,4 \%)\end{array}$ & 0,458 & 0,5 & $0,13<\mathrm{OR}<1,83$ \\
\hline & Jumlah & $39(100 \%)$ & $35(100 \%)$ & & & \\
\hline 3 & $\begin{array}{l}\text { Keterlibatan menjer } \\
\text { 1) Ya } \\
\text { 2) Tidak }\end{array}$ & $\begin{array}{l}\text { bawang } \\
14(35,9 \%) \\
25(64,1 \%)\end{array}$ & $\begin{array}{l}10(28,6 \%) \\
25(71,4 \%)\end{array}$ & 0,67 & 1,4 & $0,52<\mathrm{OR}<3,7$ \\
\hline & Jumlah & $39(100 \%)$ & $35(100 \%)$ & & & \\
\hline 4 & $\begin{array}{l}\text { Keterlibatan bersih } \\
\text { 1) Ya }\end{array}$ & $\begin{array}{l}\text { bawang } \\
25(64,1 \%)\end{array}$ & $11(31,4 \%)$ & $0,01 *$ & 3,89 & $1,4<\mathrm{OR}<10,2$ \\
\hline
\end{tabular}




\begin{tabular}{|c|c|c|c|c|c|c|}
\hline & 2) Tidak & $14(35,9 \%)$ & $24(68,6 \%)$ & & & \\
\hline & Jumlah & $39(100 \%)$ & $35(100 \%)$ & & & \\
\hline \multirow[t]{4}{*}{5} & \multicolumn{6}{|c|}{ Keterlibatan ikat bawang } \\
\hline & 1) $\mathrm{Ya}$ & $12(30,8 \%)$ & $3(8,6 \%)$ & $0,037 *$ & 4,74 & $1,2<\mathrm{OR}<18,5$ \\
\hline & 2) Tidak & $27(68,2 \%)$ & $32(91,4 \%)$ & & & \\
\hline & Jumlah & $39(100 \%)$ & $35(100 \%)$ & & & \\
\hline \multirow[t]{4}{*}{6} & \multicolumn{6}{|c|}{ Keterlibatan 'ngguris' bawang } \\
\hline & 1) $\mathrm{Ya}$ & $6(15,4 \%)$ & $8(22,9 \%)$ & 0,602 & 0,61 & $0,19<\mathrm{OR}<1,98$ \\
\hline & 2) Tidak & $33(84,6 \%)$ & $27(77,1 \%)$ & & & \\
\hline & Jumlah & $39(100 \%)$ & $35(100 \%)$ & & & \\
\hline \multirow[t]{4}{*}{7} & \multicolumn{6}{|c|}{ Personal hygiene bermain } \\
\hline & 1) Tidak Baik & $23(60,5 \%)$ & $11(33,3 \%)$ & $0,04 *$ & 3,06 & $1,15<\mathrm{OR}<8,11$ \\
\hline & 2) Baik & $15(39,5 \%)$ & $22(66,7 \%)$ & & & \\
\hline & Jumlah & $38(100 \%)$ & $33(100 \%)$ & & & \\
\hline \multirow[t]{4}{*}{8} & \multicolumn{6}{|c|}{ Personal hygiene dalam pertanian } \\
\hline & 1) Tidak Baik & $33(84,6 \%)$ & $32(91,4 \%)$ & 0,59 & 0,51 & $0,11<\mathrm{OR}<2,24$ \\
\hline & 2) Baik & $6(15,4 \%)$ & $3(8,6 \%)$ & & & \\
\hline & Jumlah & $39(100 \%)$ & $35(100 \%)$ & & & \\
\hline
\end{tabular}

\section{Diskusi}

Hubungan antara Kebiasaan Bermain Anak dengan Kejadian Goiter pada Anak

Dari hasil uji statistik Chi square didapatkan hasil bahwa tidak ada hubungan yang bermakna antara kebiasaan bermain anak dengan terjadinya goiter pada anak ( $p$ value $=0,302)$. Penyebab tidak adanya hubungan antara kebiasaan bermain anak dengan terjadinya goiter pada anak dapat disebabkan oleh faktor lokasi tempat bermain anak. Anak yang bermain di area pertanian lebih berisiko dibandingkan dengan yang hanya bermain di lingkungan sekitar rumah yang terdapat hasil produk pertanian, hal ini dikarenakan residu pestisida yang terdapat di area pertanian lebih besar dibandingkan dengan kandungan residu pestisida di lingkungan sekitar rumah. Jenis area pertanian yang digunakan anak-anak untuk bermain juga dapat mempengaruhi perbedaan paparan pestisida yang didapatkan. Kandungan residu pestisida pada lahan padi akan berbeda dengan residu pestisida pada lahan bawang, cabe, dll.

Lamanya bermain anak dan usia pertama kali anak bermain juga menjadi penyebab tidak adanya hubungan kebiasaan bermain anak dengan kejadian goiter pada anak. Menurut Suma'mur, pekerja tidak boleh bekerja 4-5 jam dalam satu hari kerja, bila aplikasi pestisida oleh pekerja berlangsung dari hari ke hari secara kontinyu dan berulang dalam waktu yang lama (Suma'mur P. K., 2013).

\section{Hubungan Keterlibatan Anak dalam Pengelolaan Hasil Produk Pertanian dengan Kejadian Goiter pada Anak}

Keterlibatan anak dalam pengelolaan hasil produk pertanian menyebabkan mereka terpapar pestisida misalnya ketika petani sedang menyemprot di sawah dan anak sedang menjemur bawang atau mengikat bawang.

Anak-anak yang terlibat dalam kegiatan melepaskan bawang dari tangkainya ('mbrodoli'), menjemur bawang, membersihkan bawang, mengikat bawang, dan mencari sisa hasil panen bawang ("ngguris) terpapar residu pestisida yang berasal dari tanah, daun/tangkai bawang, bawang merah, dan kulit bawang merah. Paparan pestisida didapatkan ketika anak sedang 'mbrodoli' bawang merah dan kontak dengan tanah, daun/tangkai bawang, serta bawang merah itu sendiri. Sedangkan ketika membersihkan bawang anak-anak lebih banyak kontak dengan tanah serta kulit bawang, ketika anak menjemur dan mengikat bawang paparan pestisida lebih

E-ISSN 2623-1204 P-ISSN 2252-9462 | 112 
JURNAL ILMU KESEHATAN BHAKTI HUSADA:

HeALTH SCIENCES JournaL, Vol. 10 No. 02, DeSEMBER 2019

DOI: $10.34305 /$ jikbh.v10i2.90
Ciptaan disebarluaskan di bawah

Lisensi Creative Commons Atribusi-

NonKomersial-BerbagiSerupa 4.0

Internasional. banyak didapatkan disaat anak kontak dengan hasil panen bawang yang masih basah dari bawang pasca dipanen, sehingga bau bawangnya sangat menyengat dan dimungkinkan paparan pestisida melalui pernapasan lebih banyak terjadi.

Penelitian oleh Narwanti, Iin Sugiharto, Eko Anwar (2012) ditemukan bahwa kisaran kadar residu pestisida golongan pyrethroid pada sampel bawang merah untuk sipermetrin $(98,8-245,6 \mathrm{ppb})$ dan sihalotrin (14,4-120,0 ppb). Terdapat kadar residu pestisida pada sampel bawang merah yang melebihi batas minimal residu, yang sangat berbahaya bagi kesehatan manusia karena bersifat toksik dan karsinogenik.

Toksisitas pestisida ditentukan berdasarkan $\mathrm{LD}_{50}$ dan jenis formulasi dari bahan aktif yang terkandung dalam pestisida. Pestisida yang banyak digunakan pada pertanian bawang merah di Wilayah Kerja Puskesmas Kluwut adalah dari golongan organofosfat dan karbamat yang apabila masuk ke dalam tubuh manusia akan menghambat kerja enzim cholinesterase (Rini Wudianto, 2008).

Mekanisme masuknya pestisida ke dalam tubuh dapat melalui kulit, mulut, dan pernafasan. Pajanan residu pestisida terjadi bila ada bahan residu pestisida yang mengenai dan/atau masuk ke dalam tubuh dalam jumlah tertentu. Pada anak-anak pajanan residu pestisida lebih banyak terpapar melalui kulit dan pernafasan dibandingkan dengan paparan melalui saluran pencernaan. Absorbsi melalui kulit atau mata akan berlangsung terus, selama pestisida masih ada di kulit.

\section{Hubungan Personal Hygiene dengan Kejadian Goiter pada Anak}

Personal hygiene anak yang buruk akan memberi peluang kontak langsung dengan pestisida sehingga pestisida masuk ke dalam tubuh. Makan atau minum setelah bermain dan terlibat pertanian dengan tidak mencuci tangan terlebih dahulu memungkinkan pestisida masuk ke dalam tubuh melalui mulut. Sedangkan jika mengganti pakaian yang dipakai untuk bermain dan terlibat pertanian, maupun tidak langsung mandi jika setelah selesai bermain dan terlibat pertanian maka pestisida masuk melalui kulit.

Pestisida yang menempel di permukaan kulit dapat meresap ke dalam tubuh dan menimbulkan keracunan. Kejadian kontaminasi pestisida lewat kulit merupakan kontaminasi yang paling sering terjadi. Tingkat bahaya kontaminasi lewat kulit dipengaruhi oleh beberapa faktor sebagai berikut toksisitas, konsentrasi dan formulasi pestisida, jenis bagian kulit yang terpapar, misalnya kulit punggung tangan lebih mudah meresapkan dari pada kulit telapak tangan, luas kulit yang terpapar pestisida, kondisi fisik seseorang makin lemah kondisi fisik seseorang, semakin tinggi risiko keracunannya (Purba, 2009).

Semakin lama anak-anak bermain dan terlibat dalam kegiatan pertanian semakin lama pula mereka terpapar residu pestisida yang terdapat pada tanah, debu, dan tanaman pertanian, dan semakin banyak pula residu pestisida yang mengkontaminasi kulit. Jenis pestisida yang paling banyak digunakan di Brebes adalah jenis organophosphat, menurut Subiyakto Sudarmo (1991) pestisida golongan organophosphat dapat menghambat kerja enzim kolinesterase sehingga mengganggu fungsi sistem kerja syaraf .

Apabila kontak pestisida dengan tubuh semakin lama maka semakin berbahaya bagi tubuh, sehingga hal yang paling penting untuk dilakukan adalah menjaga kebersihan dan menghilangkan sisa-sisa residu pestisida yang mungkin terbawa atau menempel di badan dengan melakukan personal hygiene yang baik seperti cuci tangan pakai sabun, mandi pakai sabun, mengganti pakaian, dan tidak langsung makan atau minum setelah 
JURNAL ILMU KESEHATAN BHAKTI HUSADA:

HEALTH SCIENCES JOURNAL, Vol. 10 No. 02, DeSEMBER 2019

DOI: 10.34305/jikbh.v10i2.90

bermain dan terlibat dalam kegiatan pertanian.

\section{Kesimpulan}

Ada hubungan antara keterlibatan anak dalam kegiatan membersihkan bawang $(\mathrm{p}=0,01 ; \quad \mathrm{OR}=3,89)$, kegiatan pertanian mengikat bawang $(\mathrm{p}=0,037 ; \mathrm{OR}=4,74)$, dan personal hygiene anak setelah bermain $(\mathrm{p}=0,04 ; \mathrm{OR}=3,06)$ dengan kejadian goiter.

Tidak ada hubungan antara kebiasaan bermain anak $(\mathrm{p}=0,302$; $\mathrm{OR}=3,89$ ), kegiatan melepaskan bawang dari tangkainya 'mbrodoli $(\mathrm{p}=0,458$; $\mathrm{OR}=0,5)$, kegiatan menjemur bawang $(\mathrm{p}=0,67 ; \mathrm{OR}=3,89)$, kegiatan mencari sisasisa hasil panen bawang merah 'ngguris' $(\mathrm{p}=0,602 ; \mathrm{OR}=0,61)$, personal hygiene anak setelah terlibat dalam kegiatan pertanian $(p=0,59 ; \mathrm{OR}=0,51)$ dengan kejadian goiter.

\section{Referensi}

Ejaz S, Akram W, Lim CW, Lee JJ, H. I. (2004). Endocrine Disrupting Pesticides: A Leading Cause Of Cancer Among Rural People In Pakistan. 26(2), 98-105.

Lambert, W. E., Lasarev, M., Muniz, J., Scherer, J., Rothlein, J., Santana, J., \& McCauley, and L. (2005). Variation in Organophosphate Pesticide Metabolites in Urine of Children Living in Agricultural Communities. 113(4).

https://doi.org/https://doi.org/10.1289/ ehp.6890

M Güven, F Bayram, K Ünlühizarci, F. K. (1999). Endocrine Changes In Patients With Acute Organophosphate Poisoning. 18(10), 598-601. https://doi.org/https://doi.org/10.1191 \%2F096032799678839419

Narwanti, Iin Sugiharto, Eko Anwar, C. (2012). Residu Pestisida Piretroid pada Tanah, Air, dan Bawang Merah di Desa Srigading Kecamatan Sanden
Ciptaan disebarluaskan di bawah

Lisensi Creative Commons Atribusi-

NonKomersial-BerbagiSerupa 4.0

Internasional

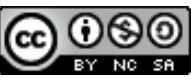

Kabupaten Bantul. Jurnal Ilmiah Kefarmasian, 2(2), 119-128. https://doi.org/10.12928/pharmaciana. v2i2.662

Purba, I. G. (2009). Analisis Faktor-Faktor yang Berhubungan dengan Kadar Kolinesterase pada Perempuan Usia Subur di Daerah Pertanian. Retrieved from http://eprints.undip.ac.id/23855/

Rasipin. (2013). Faktor-Faktor yang Berhubungan dengan Kejadian Goiter pada Siswa-siswa SD di Wilayah Pertanian di Kecamatan Bulakamba Kabupaten Brebes. Retrieved from http://repository.litbang.kemkes.go.id/ 323/

Rini Wudianto. (2008). Petunjuk Penggunaan Pestisida. Jakarta: Penebar Swadaya.

Subiyakto Sudarmo. (1991). Pestisida. Yogyakarta: Kanisius.

Suma'mur P. K. (2013). Higiene Perusahaan dan Kesehatan Kerja (HIPERKES). Jakarta: Sagung Seto.

William F. Ganong. (1999). Buku Ajar Fisiologi Kedokteran. Jakarta: EGC. 